\title{
Os bastidores do Sinaes
}

\author{
The backstage of Sinaes
}

\section{Gladys Beatriz Barreyro ${ }^{[a]}$, Dilvo Ilvo Ristoff ${ }^{[b, c]^{*}}$}

\author{
[a] Universidade de São Paulo, São Paulo, SP, Brasil \\ [b] Ministério da Educação, Secretaria de Educação Superior, Brasília, DF, Brasil \\ [c] Universidade Federal de Santa Catarina, Florianópolis, SC, Brasil
}

A entrevista a seguir foi motivada pela professora Gladys Beatriz Barreyro, logo após a saída do professor Dilvo Ilvo Ristoff da Diretoria de Estatísticas e Avaliação da Educação Superior, do Instituto Nacional de Estudos e Pesquisas Educacionais (Inep). O intuito de Barreyro foi registrar os bastidores do processo de construção e implantação do Sistema Nacional de Avaliação da Educação Superior (Sinaes). A entrevista, concedida em 27 de março de 2008, percorre os vários momentos desse processo, abordando os principais atores, conflitos, tensões, discordâncias, visões e revisões. A importância desta entrevista está, principalmente, nas reflexões que Ristoff faz sobre as discussões que levaram ao processo

GBB: doutora em Educação, e-mail: gladysb@usp.br

DIR: doutor em Literatura, e-mail: ristoff.dilvo@gmail.com 
de criação da lei do Sinaes, das inúmeras portarias que se seguiram e dos principais instrumentos (Avaliação Institucional, Avaliação de Curso de Graduação, Exame Nacional de Desempenho dos Estudantes) e índices (IDD, CPC, IGC) construídos. Ristoff mostra como essas questões expressam diferentes - e, às vezes, conflitantes - compreensões dos principais atores do processo avaliativo da Educação Superior brasileira.

Gladys Beatriz Barreyro: Dilvo, na verdade eu tenho bastantes perguntas a fazer, porque estou considerando sua participação no Comitê Assessor do Programa de Avaliação Institucional das Universidade Brasileiras (PAIUB), na elaboração desse Programa desde 1993. Até quando isso ocorreu mesmo?

Dilvo Ilvo Ristoff: Até 1996.

GB: Fale sobre a criação e a extinção do Comitê Assessor do PAIUB.

DR: O Comitê Assessor, na verdade, nunca foi formalmente extinto; ele continua existindo... Depois de junho de 1996, na prática, eu não participei mais dele, pois fui fazer meu pós-doutorado. Mesmo assim, que eu saiba, o velho Comitê Assessor do PAIUB jamais foi extinto.

GB: Ele continua?

DR: Na prática, não, porque criaram o PAIUB 2000. Não sei se isso lhe diz alguma coisa!

GB: Não.

DR: Eu explico: criaram o PAIUB 2000 e, com ele, formaram outra Comissão. Sei, de fonte segura, que fui indicado para essa nova Comissão por pelo menos dois fóruns: o Fórum da Associação Brasileira dos Reitores das Universidades Estaduais e Municipais (Abruem) e o Fórum Nacional dos Pró-Reitores de Graduação (ForGrad). Fui indicado, mas não fui escolhido pelo Paulo Renato e sua equipe... Estou lhe dizendo isso porque talvez seja importante para a história..., mas o PAIUB nunca foi formalmente extinto; ele ficou moribundo, ficou de molho, em água morna. 
Então, em 2000, tentaram reavivar o PAIUB, só que todas essas pessoas que foram para esse PAIUB 2000 eram pessoas novas, não havia ninguém do grupo antigo.

GB: Como o PAIUB surgiu? Você escreveu sobre isso nesses dois livros (Universidade em foco e Avaliação democrática para uma universidade cidadã). Que relações de força permitem a existência dele? Isso ocorreu no governo Itamar; que espaço tinha, depois do GERES, da comissão de notáveis, dos improdutivos da USP, uma proposta como a do PAIUB? É aceita essa mudança de concepção do Programa?

DR: O sucesso da ideia de avaliação do PAIUB tem sua explicação no fato de que o ministro Murílio Hingel conseguiu montar uma equipe no Ministério que era plural, filosoficamente plural. Isso foi extremamente importante: havia gente como o professor Rodolfo Joaquim Pinto da Luz, que, na época, se me não falha a memória, estava filiado ao PL, Partido Liberal; a professora Maria José Feres, que tinha uma história na Academia, como ex-presidente da Andes [Sindicato Nacional dos Docentes das Instituições de Ensino Superior] — portanto, atuante na Academia; e na presidência da Andifes [Associação Nacional dos Dirigentes das Instituições Federais de Ensino Superior] havia alguém que tinha sido ex-presidente da Andes, o professor Newton Lima Neto... Enfim, essa combinação de forças fez com que esse modelo de avaliação ganhasse espaço. Ele foi construído sob uma nova concepção, ou seja, a visão de que não é o governo que está fazendo uma nova proposta de avaliação, e sim a Andifes. É sempre bom lembrar que a raiz do PAIUB está na Andifes; o texto básico surgiu nela.

Depois disso, na época do Murilo Hingel, que ficou dois anos no Ministério, houve uma grande aproximação do governo com os pró-reitores de graduação. Em um desses encontros em Curitiba, o ministro desafiou os pró-reitores a apresentarem propostas para a avaliação e nos deu um mês de prazo para receber propostas. Meu envolvimento inicial com a avaliação está muito associado a esse momento, porque todos nós do Fórum de PróReitores de Graduação (ForGrad) decidimos, naquele Fórum, que iríamos participar da avaliação e que enviaríamos propostas ao Ministério no prazo 
de trinta dias. No dia seguinte, voltamos para casa e, trinta dias depois, só dois pró-reitores haviam enviado propostas: o professor Dilvo Ristoff, da Universidade Federal de Santa Catarina, e o professor Mozart Neves Ramos, da Universidade Federal de Pernambuco. Em consequência, na hora de definir os membros da Comissão Assessora, o ForGrad indicou pessoas que se envolveram, mandaram propostas etc. Mozart e Dilvo foram, naturalmente, indicados. Minha entrada na avaliação está muito associada a isso, mas aí a Andifes não perdeu tempo e começou a também trabalhar numa proposta, e, quando o Comitê Assessor entrou em ação, a proposta da Andifes já estava praticamente redigida e o Comitê Assessor, por assim dizer, adotou essa proposta - fez pequenas modificações, mas adotou as teses centrais da proposta que veio a ser o PAIUB. Tanto que o texto que está na introdução do PAIUB, o texto do caderno verde ["Avaliação institucional, pensando princípios"], foi produzido por mim. É de minha autoria, mas escrevi o texto interpretando as discussões que haviam ocorrido ali no Comitê Assessor, em grande parte tomando por base o texto da Andifes. Foi a melhor interpretação que eu consegui fazer à época e naquelas circunstâncias. É bom saber que foi um texto escrito muito às pressas, de um dia para o outro, literalmente. $\mathrm{Na}$ verdade, foi escrito numa tarde. São aquelas coisas que acontecem no Governo: ele convoca os dirigentes universitários do país todo para comunicar a criação do PAIUB e quase nada está preparado.

O Comitê Assessor do PAIUB chegou ao MEC, e tudo o que sabíamos era que o encontro seria na UNB. Não havia programa; nada estava organizado, não havia absolutamente nada organizado! Não nos restou outra alternativa a não ser nos sentarmos ali, em torno da mesa redonda da Sesu [Secretaria da Educação Superior], como Comitê Assessor, pessoas que vinham de todas as regiões do Brasil, e começar a organizar o evento que teria início na manhã seguinte. Parece brincadeira, mas foi assim mesmo! Como nós nos considerávamos responsáveis por tudo aquilo, decidimos fazer a nós mesmos as perguntas básicas: $\mathrm{O}$ que vai acontecer no evento? Como vai acontecer? Em que momento? Quem vai falar o quê? Como o objetivo era apresentar o PAIUB à comunidade acadêmica, decidimos dividir a apresentação em partes: um falaria dos objetivos, 
outro falaria dos princípios, outro falaria da metodologia etc. E nós, pressionados pelo tempo, rapidamente dividimos a tarefa. A mim coube falar sobre os princípios do PAIUB. Com a minha tarefa definida, tranquei-me, naquela tarde, no quarto do hotel e escrevi o texto "Avaliação institucional: pensando princípios".

GB: O texto "Avaliação institucional: pensando princípios"?

DR: Exatamente! Ele foi escrito numa tarde! Essa é a história desse texto, que pegou muito bem e que teve um impacto enorme. Chega a ser surpreendente que um texto escrito assim, absolutamente às pressas, pudesse ter tamanho impacto. Mesmo escrito às pressas, garanto que não nego nada dele; os princípios lá explicitados até hoje são muito bons.

GB: Mas não são cumpridos.

DR: É verdade! Pelo menos não todos! O Estado regulador se sobrepôs, tornando vários dos princípios inócuos, como o princípio da adesão voluntária. Nós pregávamos o princípio da adesão voluntária, e até hoje eu ainda acho que ele é um bom princípio no sentido de que poderia desvincular a avaliação da regulação. Mas perde força no Brasil, porque há um aparato legal que não permite que ele se instale. Por exemplo, a Constituição de 1988 prega que o ensino é livre à iniciativa privada, mediante a avaliação pelo poder público. Esse artigo da Constituição afirma, sem rodeios, que estamos diante de um Estado avaliador e regulador. Nós estávamos, na verdade, indo contra esse princípio, só que quase o mundo todo tem avaliação voluntária, uma avaliação à qual as instituições aderem e, se forem bem avaliadas, recebem seu selo de qualidade etc. Com base nessa avaliação e nesse resultado, enfim, as instituições são credenciadas e os cursos, reconhecidos. Aqui, não! No Brasil é obrigação! Todas as IES [instituições de ensino superior] e os cursos têm de participar. Então, nosso princípio nasceu morto, mas ele fazia muito sentido naquele contexto específico, isto é, de que o PAIUB estava essencialmente voltado às universidades públicas - instituições criadas por lei, pelo poder público, e que, portanto, não têm sua existência tão diretamente associada ao artigo 209 
da Constituição. Esse artigo se aplica essencialmente ao setor privado, o que também significa dizer, à quase totalidade (89\%) das IES. Então, como o PAIUB surgiu nas IFES [Instituições Federais de Ensino Superior], que são instituições criadas por lei pelo próprio Estado, e dificilmente o Estado vai fechar uma instituição, o princípio da adesão voluntária fazia todo sentido naquele contexto. No entanto, no momento que se começa a estender isso para as instituições privadas, ele perde sentido. É por isso, pelo contexto brasileiro, que digo que ele nasceu "semimorto".

GB: Na Comissão Especial de Avaliação, depois criada no governo Lula, com Cristovam Buarque, também foi manifestado esse princípio, não é? E como ele chega ao Sinaes?

DR: O Sinaes não adotou a adesão voluntária como princípio.

GB: Nem o Sinaes da Comissão de Avaliação?

DR: Não, o Sinaes não traz consigo todos os princípios do PAIUB. O Sinaes já está construído em outra realidade. Passaram-se dez anos, e em dez anos passaram-se muitas coisas, entre elas a Lei de Diretrizes e Bases da Educação Brasileira (LDB). A LDB também estabelece a questão da atuação da iniciativa privada. Toda a década de 90 foi um período de expansão exponencial do setor privado. Nesse novo contexto, não cabia mais trazer de volta alguns dos princípios do PAIUB, por isso nem os mencionamos no Sinaes. O que saiu no Sinaes foi isso: "a avaliação é referencial básico no processo regulatório”, ou seja, não há mais avaliação descolada do processo regulatório. Você tem de levar em conta, então, que essa avaliação vale tanto para a entrada de uma instituição ou curso no sistema da Educação Superior quanto para a sua permanência nele. Foi isso que nós colocamos lá no Sinaes. Interessante é que mesmo dentro do próprio Ministério da Educação havia gente que não tinha percebido isso. Eu tive esse cuidado, meio que a contragosto de alguns, que achavam que a entrada no sistema não tinha nada a ver com a avaliação. Minha posição com relação a isso era a de que não podíamos ter uma avaliação em cada canto do Ministério. Esta sempre foi minha luta: nunca aceitei 
que cabia uma avaliação na Secretaria de Educação Tecnológica (Setec), outra na Secretaria de Educação Superior (Sesu), outra na Capes e outra no Inep, cada uma com seus critérios, sua metodologia, seu modelo, seus procedimentos. Eram avaliações contraditórias, sem padrão MEC de referência, enviando orientações ambíguas para a comunidade acadêmica. Uma, por exemplo, exigia que a taxa da avaliação fosse paga pela instituição diretamente ao avaliador, criando um ambiente absolutamente propício à corrupção e ao suborno. Então, minha luta foi no sentido de que a avaliação se tornasse referencial básico tanto para a entrada quanto para a permanência no sistema e a saída do sistema. Sempre tive a clareza de que, diante do enorme aparato legislativo existente, o estado brasileiro havia se tornado um estado avaliador e regulador. Para isso mudar, só havendo uma mudança na Constituição brasileira - algo difícil, quase impossível de se viabilizar no presente momento histórico.

GB: Vocês, no momento em que começaram a fazer parte da Comissão de Avaliação quando Cristovam Buarque era o ministro, e manifestaram isso, não encontraram uma certa contradição em relação às questões que estavam levantando na revista Avaliação, na Rede de Avaliação da Educação Superior (Raies), dos princípios da avaliação formativa e as críticas a essa questão da regulação, que, nas origens, vocês mesmos criticaram?

DR: Sem dúvida!

GB: Como vocês assumem e lidam com essa contradição?

DR: Nós tentamos dar uma dimensão formativa a essa ideia da criação das CPAs, as Comissões Próprias de Avaliação, e, depois, em cada CPA, com seus relatórios de autoavaliação - e essa autoavaliação acontecendo como uma espécie de processo de tomada de consciência sobre as questões da instituição. Mesmo assim, sempre tivemos clareza de que, no fim, tinha de ter alguma coisa chamada de base para a regulação, porque o Estado brasileiro está solidamente construído dessa forma. Insisto: não é só a Constituição, é todo um conjunto de leis. Em algum trabalho que escrevi, eu arrolo esse conjunto de leis e mostro como elas vão se amarrando 
umas às outras, inextricavelmente. Em outras palavras: não havia condições de dizer "não vai haver regulação!"; o que não quer dizer que não há consequências; há, sim, consequências regulatórias, ou seja, a avaliação vai se expressar em reconhecimento do curso, e, se o curso já existe, vai se expressar em recredenciamento da instituição, se ela já existe. Ou não! Criamos ainda mais um elemento em meio a tudo isso, formalmente instituído, pensando na questão do sentido mais formativo do termo. A consequência não é direta, ou seja, a avaliação não tem consequência regulatória direta e imediata, no momento do resultado. Refiro-me ao Protocolo de Compromisso, que estabelece metas para corrigir eventuais equívocos, e a instituição tem um prazo para fazer isso. Só depois do Protocolo de Compromisso a consequência regulatória aparecerá. A consequência regulatória é final: quer dizer, ou há ou não há reconhecimento. Impossível fugir disso! Como se vê, essa contradição está na base e é uma diferença básica entre o PAIUB e o Sinaes. Talvez essa seja a mais importante diferença com relação ao que tínhamos pensado no PAIUB, que rejeitava qualquer consequência regulatória. Dez anos depois, essa tese do PAIUB havia se tornado absolutamente inviável.

GB: Como trabalhou a Comissão de Avaliação - essa Comissão Especial de Avaliação - e que acordos fazia? Na proposta da Comissão, havia uma certa ingenuidade de acadêmicos de universidades públicas, no que diz respeito à autoavaliação, pois parece que vocês ainda estavam um pouco com a ideia do PAIUB. Isso era claro para vocês ou foi uma elaboração da Comissão, ou de outras pessoas do Ministério, dos advogados que estavam na Comissão?

DR: Nós acreditávamos que a autoavaliação era um poderoso instrumento. Nunca negamos isso! Penso que essa era a posição de todo o grupo. É interessante lembrar que, mesmo pessoas que antes eram contrárias à ideia da autoavaliação passaram a defendê-la. Lembro-me de um debate que ocorreu, logo depois da divulgação do Sinaes, entre o professor José Dias Sobrinho e a professora Eunice Durham, em que a professora também defendeu a autoavaliação, ao mesmo tempo que defendia a 
manutenção do Provão. Foi surpreendente ouvi-la defender a autoavaliação depois de todas as suas críticas ao PAIUB, justamente por causa de sua ênfase à autoavaliação. Os tempos eram mesmo outros: ela também, de fato, defendeu publicamente a autoavaliação.

Então, a autoavaliação não era e não é uma coisa malvista. Eu até diria que, como parte do processo avaliativo, era unanimidade. Mesmo assim, ninguém tinha a ingenuidade de acreditar que a avaliação deveria se esgotar ali. Todos também defendiam a avaliação externa, e essa avaliação tinha de ter consequências, que não eram unicamente de afirmação de valores, como a gente sonhava no tempo do PAIUB, que esses valores tinham de ser afirmados e reafirmados constantemente. Já no período pós-Provão, pós-LDB e no contexto do Estado avaliador e de um sistema de Educação Superior altamente privatizado, as consequências tinham de ser também regulatórias. Com as instituições privadas, muitas delas verdadeiras empresas educacionais, era impossível pensar apenas em autoavaliação: era necessário construir um sistema que apontasse para alguma conexão entre a avaliação e o dever de regular atribuído ao Estado. A autoavaliação pura e simples era algo totalmente descartado, pois teríamos de mudar a LDB e as próprias leis, a própria Constituição. Não seria possível, por exemplo, mudar o artigo $9^{\circ} \mathrm{da}$ $\mathrm{LDB}^{1}$, que instituiu os exames nacionais de rendimento escolar em todos os níveis. Refiro-me ao artigo da LDB que cria a base para a existência de exames como o Provão, mas também do Enem e, hoje, da Prova Brasil e do Enade. José Dias, o presidente da Comissão Especial de Avaliação,

1 “Art. 9o. A União incumbir-se-á de: [...] IV - estabelecer, em colaboração com os Estados, o Distrito Federal e os Municípios, competências e diretrizes para a educação infantil, o ensino fundamental e o ensino médio, que nortearão os currículos e seus conteúdos mínimos, de modo a assegurar formação básica comum; [...] VI - assegurar processo nacional de avaliação do rendimento escolar no ensino fundamental, médio e superior, em colaboração com os sistemas de ensino, objetivando a definição de prioridades e a melhoria da qualidade do ensino; [...] VIII - assegurar processo nacional de avaliação das instituições de Educação Superior, com a cooperação dos sistemas que tiverem responsabilidade sobre este nível de ensino; IX - autorizar, reconhecer, credenciar, supervisionar e avaliar, respectivamente, os cursos das instituições de Educação Superior e os estabelecimentos do seu sistema de ensino." 
deparou-se com esta realidade: uma LDB que dizia que tínhamos de ter exames nacionais em confronto com o desejo de uma Comissão de extinguir o Provão. José Dias tentou de todas as formas fazer uma prova que não tivesse a dimensão do Provão. Foi assim que surgiu a proposta do Paideia. A ideia era de termos um exame com quatro grandes áreas. O fim dessa história nós conhecemos! O problema é que as quatro grandes áreas tornavam o exame inviável, sem a menor possibilidade de êxito, fora do grupo.

GB: Você estava falando da relação entre avaliação e regulação; o PAIUB teve como função a melhoria institucional e só está focado na instituição, já o Provão teve a função de regulação de mercado, no sentido de que seus dados eram divulgados e era uma propaganda para orientar a concorrência entre as instituições privadas. E o que está acontecendo hoje com a regulação? O Enade, ou seja, o exame nacional, está sendo utilizado para a regulação dos cursos; o Enade, sem o Sinaes (sem a autoavaliação, o processo de avaliação externa etc.), nos cursos de Direito e de Pedagogia, está exercendo essa função de regulação. Então, estamos com a questão da supervisão e desse novo indicador de cursos, o Conceito Prévio do Curso (CPC).

DR: Não, o indicador de curso está associado à ideia de que a avaliação de curso não precisa ser universal, embora universal tenha de ser a avaliação institucional. O CPC é uma forma inclusive de reforçar a avaliação institucional; ele já está na portaria que instituiu o e-MEC, o sistema eletrônico de registro de processos do MEC. A Portaria estabelece que haverá uma avaliação prévia, que foi divulgada depois da minha saída da Diretoria de Estatísticas e Avaliação da Educação Superior (Deaes) do Inep.

\section{GB: e-MEC?}

DR: O e-Mec é o sistema eletrônico do MEC que veio substituir o Sapiens. A portaria que regulamentou o e-MEC colocou uma avaliação preliminar antes de uma avaliação de curso. No Inep, estávamos trabalhando com a ideia de um conceito preliminar, que eu chamava de IQI e de IQC, um indicador de qualidade da instituição e um indicador de qualidade do curso. 
Nossa preocupação central era com o IQC, e não com o IQI. É que, como os dados favorecem muito mais a constituição do IQI, a gente brincou também com o indicador de qualidade institucional. Você pode retirar um conjunto de informações de um banco de dados, como, por exemplo, o cadastro de docentes ou o cadastro das instituições e os dados do Censo da Educação Superior, fazendo cruzamentos desse conjunto de dados com os resultados da avaliação in loco e os resultados da avaliação do Enade. Com base nesses cruzamentos, é possível construir um índice bastante confiável.

GB: O Ides, de Cristovam Buarque, no Sinapes?

DR: Não tem nada a ver com o Indicador de Desenvolvimento da Educação Superior (Ides) do Cristovam, que definiu muito vagamente o que imaginava que seria o seu Ides. O Ides foi algo tão mal explicitado que até hoje não sei qual seria de fato sua função. Talvez por isso mesmo tenha tido vida tão curta — tão curta que poucos sabem que um dia existiu algo com esse nome. O IQC teria a função de identificar se, por exemplo, um determinado curso, por meio de seus indicadores, distancia-se muito da média, ou para cima, ou para baixo. Com base nisso, poderia determinar em que curso se faria a avaliação e se ela seria feita, numa escala de um a cinco, concentrada necessariamente nos cursos um e dois, por amostragem, nos quatro e cinco, e por solicitação nos três, por exemplo. Ou talvez por amostragem, nos três, quatro e cinco, mas era uma coisa que estava em discussão quando eu saí do Inep. O que se sabia é que seria feito, embora ainda não se soubesse como. E havia profunda discordância sobre como, mas o e-MEC registrou que seria feito, inclusive o indicador não tem mais esse nome que eu dei: IQC. A sigla IQC foi uma invenção minha, para simplificar a conversa. Como eu dizia, tivemos grandes discordâncias sobre a maneira de construir o indicador. Essa discordância inclusive ficou registrada numa carta que encaminhei ao presidente do Inep, aos secretários e ao próprio ministro, em outubro do ano passado. Minha discordância tem a ver com a âncora desse indicador, que toma por base essencialmente o Enade. Eu sempre me opus a isso, por questões conceituais. Penso que o Enade é muito limitado para servir de âncora. Na cabeça do Reynaldo Fernandes, 
presidente do Inep, a fórmula seria mais ou menos assim: nós teríamos um conjunto de indicadores, que poderíamos chamar de " $x$ ", e esses indicadores de alguma forma estariam correlacionados, fortemente correlacionados, a duas coisas do Enade, o conceito e o IDD do curso. Ora, os dois são conceitos vinculados à norma, associados a uma distribuição normalizada. É um mero modelito que diz que sempre teremos tantos por cento de conceitos um, dois, três, quatro, cinco ou, se quisermos, de cem etc. Reynaldo acreditava que dessa correlação surgiria uma coisa chamada qualidade. Minha discordância em relação a isso tem a ver com, primeiro, a natureza do conceito e do IDD e a forma como ele é construído, repito, como modelito. E, segundo, porque esse conceito não mede um conjunto de coisas, como a má vontade do estudante ao responder a prova. $\mathrm{O}$ conceito não consegue medir adequadamente o efeito de um boicote, que não é cem por cento visível; não consegue medir, por exemplo, a diferença de nível de ingresso dos alunos. Tudo isso faz parte de um exame desse tipo, mas especialmente não reflete o que é um curso no seu todo, muito menos numa universidade.

GB: Então você voltaria a dizer o que falava do Provão?

DR: Exatamente, o que eu dizia é o seguinte: existem valores nos quais nós acreditamos, e esses valores estão explícitos em nossos instrumentos de avaliação. Todos eles estão lá, ou seja, não vamos ter "x" e "y", vamos ter só " $x$ ", essa é a proposta com a qual respondi. Nesse " $x$ " nós vamos ter informações, como: o percentual de doutores no quadro; a relação doutor/aluno (quantos doutores a IES ou o curso tem por aluno), a relação doutores/mestre etc. Eu cheguei a arrolar uns trinta ou quarenta indicadores " $x$ ". Se déssemos um ponto para cada um deles e os colocássemos numa escala de um a cinco, poderíamos ter uma ideia de como a IES ou o curso se posiciona com relação à média nacional, regional ou estadual. Se a média de doutores no quadro for de vinte por cento no país, então poderíamos, a partir disso, criar uma escala, estabelecer pesos e criar conceitos. Algo assim: se estiver acima da média, atribuímos conceito quatro; se estiver muito acima, atribuímos um cinco; se estiver abaixo da média, 
atribuímos um dois; e se estiver bem abaixo, atribuímos conceito um. Isso poderia ser feito para cada indicador, e essa foi a proposta que eu defendi. Por quê? Para não fugir daquilo que é essencial na avaliação: a afirmação de valores.

GB: Vocês fizeram algum tipo de simulação?

DR: Fizemos, sim! Eu estava esperando a simulação do Reynaldo Fernandes, que ainda não tinha acontecido, mas imagino que, no fim, não dê um resultado tão diferente assim, o resultado nesse caso importa pouco: a diferença fundamental está na forma de conduzir, induzir ou de afirmar valores...

GB: Legitimidade.

DR: Eu não diria só legitimidade, mas também afirmar valores para a comunidade acadêmica. Dizer a ela, claramente: ter doutores é importante, ter mestres é importante. São valores que não são absolutos, mas nos quais nós acreditamos para assegurar a qualidade.

GB: Mais do que esses valores, isso também está na lei...

DR: Para as universidades está, mas para as faculdades, não.

GB: E para os centros universitários.

DR: Para os centros universitários também é exigência, mas para a grande maioria das IES, as faculdades, não há exigência de doutores e mestres. Poderíamos nos perguntar: mas por que está na lei? A resposta é: porque se acredita que é importante. Essa também foi uma discussão devidamente registrada e que ainda não terminou. Eu não participei do fim dela e sei que o índice está sendo construído; espero que tenham o bom senso de não ancorar tudo no Enade, porque ele não considera questões ligadas ao esforço de extensão, esforço de ensino e um conjunto de informações que hoje o MEC e o Inep têm e que podem e devem usar para a avaliação. Essa é a grande ideia que busquei materializar no portal Sinaes. 
GB: E aquela sua ideia da transparência, para que toda pessoa pudesse acessar uma instituição com todas as informações, mas que todas essas avaliações fossem rápidas e que se pudesse ter essa possibilidade?

DR: Há uma parte da supervisão, que não está necessariamenteligada à avaliação; ela está ligada a outras questões. Por exemplo: se eu for fazer a avaliação de cursos hoje e constato que a IES tem trinta por cento de doutores em um quadro e na outra semana tem onze, e na outra semana tem só dois, não posso dizer que a avaliação foi mal feita. O que pode estar acontecendo e isso está acontecendo - é uma manifestação de má-fé institucional e até de corrupção institucional. Nesse caso, o remédio não é mais a avaliação, mas a supervisão. Então, há elementos de supervisão que vão muito além da avaliação. A supervisão estava morta, estava inexistente no MEC até o ano passado. Nenhuma denúncia foi apurada a rigor; recebíamos denúncias de todos os tipos: de professores que não cumprem a carga horária, de programas que estão totalmente desvinculados das diretrizes nacionais, instituições que deliberadamente não informam corretamente os dados etc. Até pode ser que tenham prestado informações equivocadas. Cabe verificar, mas isso é papel da supervisão e, para isso, há de se usar o poder de polícia do estado, não a avaliação.

GB: Porque supervisão é atividade do poder de polícia do Estado.

DR: Exatamente! Inclusive é esse o termo usado no parecer jurídico; é o poder reconhecido do Estado. Supervisão é diferente da avaliação, avaliação não tem poder de polícia. Portanto, há de se ter a clareza de que a avaliação é extremamente importante, e o que nós estamos discutindo aqui é o quanto da avaliação pode ser usado para instruir o processo de supervisão e que cuidado se deve ter.

GB: Para que seja legítima e válida.

DR: Claro, para não desvalorizar a avaliação, não colocar em risco toda a ideia central da avaliação, que é a afirmação de valores. 
GB: Mas por que os outros tantos pedidos não são apurados, a não ser o pedido da OAB?

DR: Boa pergunta! Porque a OAB é muito forte.

GB: Quer dizer: são os lobbies se perpetuando na Educação Superior brasileira...

DR: Claro! Diga a que instituição pertences e eu te direi quem faz lobby por ti em Brasília! Alguns lobbies são, de fato, muito fortes. O caso da OAB é o seguinte: o humor do país diz que há cursos de Direito demais, cursos de Medicina demais etc. Todos concordam quando se diz que $12,1 \%$ dos jovens na Educação Superior é muito pouco para um país como o nosso, todos concordam e afirmam que precisamos de mais jovens [nas IES]. O problema é que isso vale para colocar esses jovens em outros cursos, não no que você frequenta ou naquele em que você se graduou. Em 1971, a associação dos médicos, com a Sesu, publicou um texto que dizia que havia médicos demais no país. Pergunto: Que visão de futuro, de sociedade tem um grupo desses? Médicos demais no Brasil em 1971? Parece brincadeira! Não estão vendo nada além do próprio umbigo...

GB: E da distribuição geográfica...

DR: Quando se pensa em um país que precisa crescer...

GB: Quando se tem municípios sem médicos.

DR: Pois é, temos estados que não têm um único médico formado. Poderiam pelo menos propor: "olha, vamos tentar criar uma ênfase de expansão em outros estados; vamos induzir a expansão para outros setores...". Mas não, a ideia é sempre fechar, para não banalizar a profissão. Isso está escandalosamente explícito! Enquanto isso, 40 candidatos continuam disputando uma única vaga, em média, no Brasil, e 39 jovens terão de se contentar em estudar o que não querem. 
GB: É corporativismo.

DR: É, sim, é corporativismo. Essa tese não se sustenta fora do grupo, e tudo o que não se sustenta fora do grupo específico tem esse nome: corporativismo. E no curso de Direito, eu pessoalmente acho muito estranho que se faça lobby pelo fechamento de curso, com base na Ordem dos Advogados do Brasil: porque é constatado inclusive estatisticamente que só 50\% dos bacharéis formados em direito trabalham em áreas ligadas a direito; eles trabalham em outras áreas em que a sociedade demanda pessoas com esse tipo de formação, que aparentemente se aproveitam dessa situação. Um terço dos engenheiros trabalham com engenharia e só $75 \%$ dos médicos formados trabalham com medicina. Você tem uma mobilidade que vai muito além da formação do bacharel. O advogado é uma parte pequena de dezenas de outras atividades que podem ser exercidas com esse tipo de formação. Além disso, a OAB seleciona os advogados pelo Exame de Ordem.

GB: Você leu a desculpa do dono de uma IES privada de que a qualidade do curso de Direito é relativa, que muitos dos estudantes não iriam advogar. Então, estava justificando que o curso dele tinha nota 1 no Enade, mas que ele estava contribuindo.

DR: E, de certa forma, estava mesmo. Não podemos tirar o direito da $\mathrm{OAB}$ de dizer assim: "vamos estabelecer níveis de exigência para o exercício profissional", mas, para isso, ela tem, repito, o Exame. Então que o aplique com o rigor que julgar razoável. No entanto, o indivíduo que quiser estudar Direito, deve ter o direito de estudar Direito. Ele pode nunca querer exercer a profissão, assim como tem gente que estuda Sociologia e nunca vai exercer a profissão de sociólogo ou de professor de Sociologia. É sabido que muitas pessoas, e, em alguns casos, a maioria delas, não exerce a profissão para qual estudou.

GB: Mas assim você estaria justificando a baixa qualidade do curso...

DR: Não estou justificando nada; não estou dizendo que o curso tem boa ou má qualidade; estou dizendo que, como orientador de política educacional, o resultado no Exame de Ordem é flagrantemente insuficiente. 
É necessário julgar por outros critérios de qualidade, mas não pelo exame da $\mathrm{OAB}$. $\mathrm{O}$ exame da $\mathrm{OAB}$ não fala em qualidade e, na minha opinião, não pode determinar política de regulação educacional; ele não pode determinar a política para a Educação Superior do país; se um indivíduo quiser estudar Direito, deve existir espaço para que estude. Deixe-o estudar: ele fará uso do que aprendeu em outros ambientes, a vida valida o que estudamos, mesmo que alguma estrutura burocrática ou corporativa não valide.

GB: Você já escreveu isso?

DR: Já escrevi, com certeza; escrevi algo parecido, referindo-me a meu caso particular - eu, que fiz dois anos e meio de Direito. O que estou colocando, neste momento, mexe com questões muito delicadas e sobre as quais há bastante controvérsia. A supervisão do direito está muito ancorada nos conceitos do exame da $\mathrm{OAB}$, mas conceitualmente eu não tenho dúvidas de que há uma contradição, no sentido de que isso possa ser usado para definir a política. A OAB é um órgão corporativo com todos os direitos de estabelecer critérios para o exercício profissional, não para definir políticas de expansão ou de encolhimento do Ensino Superior em qualquer curso, nem mesmo no de Direito, porque Direito não é só isso, ele é útil até para a formação geral dos indivíduos. Nem todos pensam assim, e essa é uma questão que tem gerado historicamente muitas controvérsias!

GB: Você disse, no livro Avaliação: construindo o campo e a crítica, de Luiz Carlos Freitas, que foi suplente de Isaura Belloni no PAIUB, numa reunião à qual ela não podia ir...

DR: Na verdade, eu fui substituir a professora Isaura Belloni num evento da Andifes, eu acho, e isso me forçou, de uma hora para a outra, a ter de organizar um pouco a discussão. Mas eu já estava no Comitê Assessor e fui ao evento porque ela não pôde; ela era muito requisitada à época e não conseguia atender a todas as demandas.

GB: Ainda sobre o PAIUB, qual é sua opinião sobre as avaliações institucionais decorrentes dele, especialmente a da UNB, que na verdade foi 
anterior à da Unicamp? Eu verifiquei também uma de Feira de Santana, uma da UFRGS e outras. Quero sua opinião geral sobre isso.

DR: Conheci todos esses processos avaliativos que mencionas. O de Feira de Santana talvez tenha sido o mais problemático, porque ele nada mais era do que um rol de manifestações da comunidade acadêmica.

GB: Checklist.

DR: Não, não era checklist, era um rol de manifestações vindas da comunidade acadêmica, sem qualquer sistematização, sem qualquer análise ou síntese. É um pouco do meu preconceito: eu acho que todo número tem de ser analisado, toda manifestação tem de ser analisada. Para mim, a própria ideia da avaliação está ligada a análise, síntese e interpretação. Sou socrático nisso; Sócrates achava que a vida não avaliada não vale a pena de ser vivida...

GB: Os psicanalistas não param de falar disso.

DR: Não vale a pena, senão você é um vegetal, apenas uma coisa que aparece. Quando avaliamos, no entanto, nós nos perguntamos o significado. É mais do que eu vejo superficialmente. O que vale, o que de fato importa, é o impacto que tem minha inferência. Nos processos em que não há inferências e não há juízos não há avaliação. O que Feira de Santana fez, repito, foi um rol de coisas perfeitamente contraditórias. Faltou a trama. Como já dizia Aristóteles: "O mundo não tem trama, a trama é um construto humano sobre o mundo". Ligar as peças, combinar, estabelecer relações e, então, inferir e julgar torna-se fundamental.

A base da poética de Aristóteles é essa, e é por isso que dizem assim: o espetáculo pode ser muito bom, mas a trama, uma droga. Então, a boa tragédia é aquela que tem uma boa trama, mas essa trama não existe na vida em si, ela tem de ser construída. Você tem de juntar as partes e construir um crescimento, que vai levar a um bom momento, a um clímax. O grande problema que eu vi naquela avaliação de Feira de Santana foi esse. $\mathrm{Na} \mathrm{UNB}$, a avaliação não tinha uma dimensão institucional muito crítica; ela era totalmente centrada em curso, como também foi o caso da 
UFRGS. A grande diferença dessas avaliações e o que preconiza o Sinaes é isto: a distinção muito mais nítida entre avaliação de curso e avaliação de instituição.

GB: Na Unicamp também foi centrada em cursos.

DR: Também, também!

GB: Mas eles estão cientes disso. Sobre o PAIUB ainda, houve contatos com as autoridades do MEC quando o Provão foi implantado? Pedidos de entrevistas com vocês do PAIUB, ou continuaram separadamente com o PAIUB e o Provão?

DR: Não, continuaram separadamente, não houve articulação alguma. O que aconteceu é que o Provão caiu assim, de repente. Ele se tornou lei, a rigor, com a LDB e foi lançado. A comunidade acadêmica o foi recebendo e, à medida que sua propagação foi conseguindo resultados, algumas instituições começaram a fazer seus outdoors de publicidade porque tinham tido bom desempenho. A partir daí, o PAIUB começou a ser esquecido. Eu me lembro muito bem de um caso - em algum lugar eu escrevi sobre isso - , acho que é o de Cáceres no Mato Grosso. Fui para Cáceres, no segundo semestre de 1995 ou no primeiro semestre de 1996, e eles tinham um bom programa de avaliação institucional, com gente muito empenhada e tentando dar continuidade a ele. Surge de repente o tal do Provão, e eles, naquele ano, tiraram A no Provão de Direito, que era uma coisa absolutamente inédita para eles. Não deu outra: esqueceram do PAIUB! Ninguém queria mais falar em avaliação. Avaliação era o Provão; outdoors, todo mundo feliz, reitores felizes, pró-reitores felizes: "nossa universidade, aqui no interior do Pantanal, tira A, nosso curso está entre os melhores do Brasil...". Aí, no ano seguinte, no Provão, tiraram $C$ e nunca mais tiraram $\mathrm{A}$. Inclusive, eu consultei a professora e perguntei por que tiraram $\mathrm{A}$ naquele primeiro ano, e eles chegaram à conclusão de que era porque todos os alunos já tinham [se graduado em] outro curso universitário. Era um grupo pequeno que tinha feito o exame e, por serem mais experientes, eram também mais bem preparados. 
GB: A criação da Raies e da revista Avaliação são uma consequência do Provão tomando o lugar do PAIUB.

DR: Total, total.

GB: Vocês foram a um encontro, assim que surgiu o Provão? Decidiram criar a revista para difundir as ideias da avaliação institucional?

DR: É, fomos a um encontro em Recife que, para mim, foi histórico. Participaram dele vários representantes do Ministério da Educação na época, entre eles a Maria Helena Guimarães Castro.

GB: Maria Helena, a atual Secretária da Educação do estado de São Paulo? DR: Isso! Estavam presentes Cid Gesteira, Vanessa Guimarães, que era a Secretária de Educação Superior, e nós, pacientemente ouvindo esse povo todo falar. Fala após fala, nós começamos a chegar a uma conclusão na verdade, o professor José Dias Sobrinho estava mais otimista do que eu. Eu me lembro que disse a ele: "Zé, vamos analisar não o texto, mas o subtexto. Aqui eles estão dizendo isso, mas, na verdade, o que eles estão fazendo é negando nosso princípio tal do PAIUB. Isso aqui afirma isso, mas no fundo estão negando o outro princípio...". Então, quando vimos que todos os princípios estavam sendo negados, eu disse: "Zé, se é assim, então acabou o PAIUB!”. “Escuta, Zé, o PAIUB morreu, morreu!”. E foi então que decidimos fazer uma revista para garantir um espaço de discussão e, é claro, de contestação. E saímos do Recife com o primeiro número da revista pago; nós reunimos um grupo de pessoas que compraram todo o primeiro número, que foi distribuído gratuitamente.

GB: O lançamento dessa revista não teve consequências perante o Ministério?

DR: Acho que não! Talvez um pouco. Várias vezes ouvi dizer que o ministro não gostava de nós, eu só ouvia dizer isso... Talvez a não aceitação do meu nome, nem o do Zé Dias para o PAIUB 2000, esteja associada a isso. Deixou a impressão, considerando-se que vários fóruns nos indicaram, de que nós éramos personas non gratas para o Ministério. 
GB: Nunca foram chamados para conversar com ele?

DR: Nunca, jamais! No primeiro ano do ministro Paulo Renato, eu era presidente do Fórum Nacional dos Pró-Reitores de Graduação das Universidades Brasileiras e, como presidente, tentei abrir caminhos de todas as formas. Procurei a secretária da Sesu, procurei o primeiro secretário, o Décio Zagottis, que depois veio a falecer repentinamente.

GB: Você já falou de Cid Gesteira...

DR: Cid Gesteira não era o secretário, ele era diretor de políticas e representou uma mudança radical no Ministério. Ele se tornou o diretor que substituiu a professora Maria José Feres, e os dois pareciam água e vinho, um não tinha nada em comum com o outro.

GB: Ele fez parte do PAIUB?

DR: Não, o Cid não tem nada a ver com o PAIUB.

GB: Mas ele aparece como representante da Sesu.

DR: Isso no PAIUB 2000, não no PAIUB. Cuidado para não confundir os dois.

GB: Não houve nenhum tipo de resgate dos instrumentos do PAIUB para o Provão, para o Ministério, nem uma conversa?

DR: Não, o que eu percebi é que, no último ano do governo Paulo Renato, no oitavo ano, ele estava recuperando coisas do PAIUB. Eu só descobri isso por meio de um pessoal que trabalhava no Inep e que me apresentou algumas dessas informações, mas duvido que teria vingado com ele à frente.

GB: Outra pergunta sobre a revista Avaliação: o Cipedes [Centro Interdisciplinar de Pesquisa para o Desenvolvimento da Educação Superior], que apareceu em 1999, como e por que ele surgiu, qual seria sua função? É um pouco estranho, porque olhando a revista, aparece essa separata. Enfim, queria alguns comentários sobre isso, você aparece como secretário executivo... 
DR: A ideia do Cipedes surgiu porque a revista Avaliação, com o tempo, estava se tornando uma revista da Educação Superior como um todo. Pensamos, então, que para não perder a identidade mais específica da avaliação, poderíamos ter uma separata, porque havia demanda para isso. Nós não queríamos tolher esse tipo de manifestação, e surgiu a ideia de criar um centro. O Hélgio Trindade surgiu com a ideia de criar o Centro Interdisciplinar de Pesquisa para o Desenvolvimento da Educação Superior. E ele ligou isso ao grupo que havia em Porto Alegre; a ideia era de que a revista teria uma separata, como uma parte dela.

GB: Em algum momento vocês pensaram em se constituir como um grupo oposto ao grupo Nupes (Núcleo de Estudos e Pesquisas sobre o Ensino Superior), do eixo tucano?

DR: Não, não oposto! Éramos, na prática, um grupo com alguma identidade em torno de alguns interesses e atividades.

GB: De confronto...

DR: Não, não de confronto. Estou falando de um grupo a mais, que estava estudando a Educação Superior, mas é claro que tínhamos algumas resistências àquele grupo, talvez nem tanto pelas ideias, mas pelos vínculos políticos. O grupo do Nupes sempre transitou numa esfera muito restrita politicamente. Nós estávamos um pouquinho mais à esquerda daquele grupo. Pelo menos nós nos considerávamos mais à esquerda.

GB: Por que tão restrito? Não entendo muito bem, porque de alguma forma se pensa que, na verdade, o modelo atual da Educação Superior do país foi criado pelo Simon Schwartzman, pelo Nupes, pela Eunice.

DR: Quem escreve sobre as políticas agora, quem escreve sobre o Enade, é o Schwartzman; ele vai lá, dá pau no Enade, mas não leu nada, ou leu mal; não entendeu nada e vai lá dar pau. Não queira me dizer que ele não tem condições de fazer uma análise científica mais decente; ele fez uma análise que é um escândalo. Pensei até em escrever um texto chamado 
"O enigma de Simon", mas achei que não valia a pena! Aquela crítica dele não merece resposta! Ele é um sujeito competente, sabemos disso.

GB: Ele escreveu uma matéria faz tempo, quando saiu o Enade, ou foi algo mais?

DR: Não, foi isso mesmo, mas nenhum outro membro do Nupes foi lá e fez uma análise, foi o Schwartzman. Ele divulgou para o mundo, mas quando você analisa e vai a fundo para entender seu argumento, não encontra nada que o sustente. Ele conseguiu, com todos os seus anos de estrada, escrever sobre algo que não estudou. Só posso concluir que teve motivação ideológica.

GB: Houve participação de alguma pessoa do PAIUB na gestão Paulo Renato? DR: Estou achando que houve em algum momento; mas você teria de checar, eu acho que em algum momento o Carlos Bielschowsky participou, mas não estou certo disso!

GB: Ele está na revista Avaliação?

DR: Está, sim.

GB: Você se manifestou publicamente sobre o Provão em vários textos. O que pensa hoje em dia sobre o Provão? Continua pensando a mesma coisa?

DR: Continuo!

GB: Em que medida algumas questões que você criticava sobre o Provão foram reproduzidas pelo Enade? Porque foi difícil fugir disso?

DR: A crítica ao Provão esteve sempre ligada ao isolamento do Provão como instrumento básico, único, diretamente associado à regulação. Eu sempre fui contra isso, e até hoje sou, com a tensão que eu vivo em relação a seu uso para fins de supervisão. Continuo com a mesma ideia, de que esse isolamento do Exame, seu uso isolado, não é bom, é prejudicial.

O Exame Nacional de Desempenho do Estudante (Enade) pode ser descrito como um exame construído por especialistas, tomando por base não o perfil 
do concluinte, mas o perfil do curso. Esse perfil envolve competências e saberes em seu cruzamento com os conteúdos aos quais os estudantes devem ser expostos durante sua trajetória acadêmica. O Exame foi construído, portanto, não sobre o ponto de chegada, mas sobre a trajetória do estudante. Isso equivale a dizer que o Enade se ocupa com conteúdos de todo o espectro das diretrizes curriculares, e não apenas com conteúdos profissionalizantes. Por estar centrado na trajetória, e não no ponto de chegada, o Enade é composto por questões de baixa, média e alta complexidades. E, por ser assim, o Exame pode ser respondido por ingressantes e concluintes, permitindo aos concluintes uma revisão dos conteúdos estudados durante todo o curso e, aos ingressantes, a percepção do quanto sabem e do quanto ainda não sabem dos conteúdos aos quais serão expostos. Assim, uma característica marcante do Enade é o fato de ele ser aplicado simultaneamente a ingressantes e concluintes, permitindo identificar o nível de ingresso e de saída dos alunos, ajudando a orientar as instituições sobre a necessidade ou não de fazer ajustes ou revisões curriculares.

O Enade tem, ainda, questões comuns a todas as áreas do conhecimento, questões de formação geral e questões de ética e de cidadania consideradas por especialistas como importantes a todos os universitários, independentemente de suas áreas de especialização. O Exame inclui, pois, questões instrumentais que têm a ver tanto com a formação do profissional quanto com a formação do cidadão.

Extremamente importante é perceber que a nota do Enade não é a nota do curso, mas parte da nota do curso. Portanto, nenhuma decisão regulatória será tomada em função apenas do desempenho dos estudantes. A nota no Enade será somada à nota obtida pelo curso durante a avaliação in loco, feita periodicamente por comissões de especialistas. Como a nota no Enade não será considerada igual à qualidade do curso, ela não será, por consequência, usada para fazer ranqueamentos.

A aplicação do Enade é feita anualmente por grupos de áreas. Cada grupo é submetido ao Exame somente a cada três anos, sempre com aplicação concomitante aos ingressantes e concluintes. Isso permite avaliar um número bem maior de áreas, além de possibilitar uma melhor avaliação dos 
ajustes feitos desde o último Exame. O Enade, em três anos, atingiu 48 áreas do conhecimento. Convém lembrar que, em oito anos de existência, o Exame Nacional de Cursos atingiu 26 áreas.

A exemplo do que acontecia com o Exame Nacional de Curso, o Enade solicita aos estudantes o preenchimento de uma questionário sócio-econômico-cultural. Esse questionário é aplicado agora não só aos concluintes, mas também aos ingressantes. Dessa forma, teremos possibilidades de entender como os estudantes veem o curso quando ingressam nele e como o veem alguns anos mais tarde, quando saem dele. Isso representa ganhos significativos na compreensão das questões que definem a vida do estudante no campus.

Dada sua natureza, o Enade gerará diversos tipos de nota: nota dos ingressantes na parte específica; nota dos concluintes na parte específica; nota de ingressantes e concluintes nas partes geral e comum; e um indicador de diferença de desempenho, mostrando o quanto a média dos alunos mudou durante a trajetória pelo curso.

Resumindo: o Enade apresenta marcantes diferenças em relação ao antigo Exame Nacional de Cursos. Ele difere no tipo, no destinatário, na periodicidade e na forma de aplicação do exame, no tipo de resultados produzidos, no uso desses resultados, no questionário a ser aplicado aos alunos, no questionário a ser aplicado aos coordenadores.

Esses aperfeiçoamentos, no entanto, perdem sentido se não forem vistos no contexto das importantes mudanças introduzidas na avaliação da Educação Superior brasileira, com a criação do Sinaes — o novo Sistema Nacional de Avaliação da Educação Superior. O Enade é parte integrante desse sistema e precisa ser visto nessa relação. Tomar os resultados do Enade de forma isolada significa produzir rankings baseados em juízos apressados, sem confiabilidade, injustos com os cursos avaliados e que pouco ou nada contribuem para a melhoria da qualidade das atividades acadêmicas.

$\mathrm{Na}$ verdade, então, os dois exames só têm em comum uma coisa: eles são exames de larga escala. A partir daí, tudo é diferente! Agora, o coordenador do curso pode analisar, digamos, a questão 40 da prova e verificar se seus alunos ingressantes se saíram muito bem ou muito mal. Pode fazer 
isso com qualquer uma das quarenta questões, o que permite trabalhar a deficiência ao longo do curso muito mais nitidamente do que com o Provão. O Enade, então, é muito diferente do Provão: ele entra no instrumento de avaliação in loco do curso como uma pequena parte. Penso até que deveria ter um peso um pouco maior do que tem; se comparado com o Provão, seu peso é muito pequeno na avaliação do curso.

GB: Não haveria uma contradição entre essa função do Enade no interior da instituição e o fato de ele ser de larga escala? Porque é muito difícil que o Enade seja valorizado, nesse sentido, pela comunidade. É um investimento importante feito pelo Ministério, aplicado a todas as instituições, mas seu aproveitamento será principalmente dentro da própria instituição.

DR: Não, eu não estou dizendo isso! Penso que o Enade faz muito sentido também na busca de informações gerais, para o país. Ele não tem só esse sentido no âmbito do curso; a ideia de situá-lo no âmbito do curso e de desvinculá-lo do processo regulatório tem a ver com a natureza de evento que ele, por suas dimensões, adquire naturalmente. Quando, em um único dia, são mobilizadas quinhentas mil pessoas, temos um evento. Qualquer atividade que mobilize quinhentas mil pessoas num só dia, em qualquer parte do mundo, é um evento.

GB: Mas só aqui no Brasil existe o Enade, o Provão!

DR: Com essas características, sim. Mas o que eu quero dizer é que um evento, seja ele qual for, um jogo de futebol ou uma procissão religiosa, quando reúne quinhentas mil pessoas, é um evento - algo que todo jornalista persegue e sobre o qual quer saber mais para divulgar. Assim é o Enade: um evento na hora da divulgação e também um evento no dia da prova.

GB: Ele não poderia funcionar como está funcionando agora a Provinha Brasil, um elemento que o Ministério está disponibilizando para as prefeituras, para os Estados utilizarem, mas que não obrigatoriamente tem seus resultados enviados ao Ministério. 
DR: Não, acho que não, porque o Enade, esse exame de larga escala, tem uma importância muito grande no sentido de permitir comparações, que fazem parte da possibilidade de análise, de interpretação. Poder pegar o resultado da prova e dizer assim: nessa questão aqui, a minha instituição acertou cinquenta por cento, mas a média é setenta por cento no país. Isso tem importância, porque cria um referencial. Então, se esse setenta por cento é uma coisa fácil no país, como e por que meu curso fica aquém? Quero saber! Quero descobrir os motivos. Na minha região, na escola vizinha, essa comparação é importante para saber onde eu estou, onde se situam meus alunos. Uma das coisas mais importantes do Enade, e também era do Provão, é o questionário socioeconômico. Ele é extremamente útil em termos de orientação sobre quem é a população com a qual trabalhamos em nossos cursos e instituições.

GB: Ainda sobre a Comissão de Avaliação do governo Lula, queria saber qual é a gênese dela, se teve algo a ver com sua participação no Plano de Governo - Uma Escola do Tamanho do Brasil —, se influiu na criação da CEA e depois em sua nomeação no Inep, se foi iniciativa do Cristovam Buarque ou se do Hélgio Trindade (que foi o coordenador desse Plano).

DR: O Professor Hélgio não foi o coordenador do programa do Lula. O coordenador foi o Newton Lima Neto, que todos achávamos que seria o Ministro da Educação.

GB: Sim, é verdade, eu me confundi. E os acadêmicos das universidades públicas que estavam no governo, o Antunes, o Otaviano, o Mario Pederneiras, estiveram à frente da criação dessa Comissão?

DR: Quase todas essas pessoas se conheciam pessoalmente, por causa de sua própria história. Mário Pederneiras, Hélgio Trindade, José Dias Sobrinho, Carlos Antunes - que era presidente da Andifes -, todos se conheciam e sabiam, de certa forma, do trabalho dos outros. O Antunes foi convidado pelo Cristovam para ser Secretário, mas, como eu já disse, ele tinha sido presidente da Andifes no mandato anterior, e essa vinculação com a Andifes e a Sesu é naturalmente próxima, por causa da própria natureza 
de mantenedora que o MEC tem em relação às IFES. Então é por isso que a Andifes está muito presente, muito mais que qualquer outra associação de reitores. O Programa de Governo apenas estabeleceu a revisão da avaliação (na proposta doze). Claro, eu estava presente nessa comissão, o Hélgio e eu. O José Dias participou só como pessoa ouvida; ele enviou sua contribuição por escrito, mas ele não participou das reuniões.

GB: O Newton Lima chamou vocês?

DR: Eu não lembro quem me chamou, mas acredito que tenha sido o próprio José Dias, que já era o presidente da Comissão. Ele não aceitaria participar se não ocupasse a presidência.

GB: Por quê?

DR: Em função de toda a história da avaliação da Educação Superior nesses anos todos. O Zé e eu tínhamos uma longa história na avaliação, depois de termos ficado oito anos na trincheira, na resistência, publicando a revista Avaliação... Confesso que quando nos chamaram, em abril, eu estava muito incomodado com o fato de que, na avaliação do Inep, por exemplo, não havia uma única pessoa que tivesse alguma coisa a ver com a história da avaliação na última década. E asseguro que não era só eu que pensava assim! Eu estava incomodado, e claro que nós conversávamos, trocávamos ideias, e-mails e nos perguntávamos: "Quem, afinal, é Otaviano Helene, quem é Luiz Araújo?”. Eu os conheci no Inep e garanto que são boas pessoas, dedicadas, gentis, mas, na questão da avaliação stricto sensu, nunca haviam participado do debate nacional. Quem tinha trabalhado com a avaliação de forma organizada e sistemática era o Zé Dias e eu. Na trincheira, na resistência. O fato de a proposta doze constar do Plano de Governo devia-se diretamente ao Zé e a mim. Por tudo isso e outras coisas mais, tenho a clareza e a certeza de que o Zé não aceitaria jamais, naquele momento histórico, participar como mero coadjuvante. Ele era o protagonista natural e, por isso, se tornou presidente, apesar de algumas resistências.

GB: Mas a CEA não foi iniciativa do Cristovam? 
DR: Não, foi da Sesu; a iniciativa foi da equipe do Antunes.

GB: E como foi a relação do Cristovam com a CEA?

DR: O importante nessa questão é saber que a Sesu tomou essa iniciativa especialmente porque houve um evento muito complicado, aqui em Brasília, promovido pelo Inep, o qual colocou a comunidade acadêmica em polvorosa, por causa das posições que estavam sendo tomadas por pessoas "estranhas ao ninho". Então a Sesu chamou para si a responsabilidade.

GB: Aquele evento que fizeram no início do governo Lula?

DR: Bem no início do governo Lula.

GB: Não tenho lido nada sobre esse evento, há alguma publicação?

DR: Não, eu acho que nunca foi feito publicação alguma; a maioria das pessoas queria esquecer aquele evento.

GB: Por quê?

DR: Porque foi muito ruim. As informações que tenho - eu não participei do evento - são de que não poderia ter sido pior. Paguei um preço alto pelo evento sem ter participado.

GB: Quem participou dele?

DR: O José Dias participou. Eu não participei porque tinha organizado um evento internacional e era o presidente da Comissão, não podia me ausentar naquele momento. Mas fui convidado a participar; a maioria das pessoas envolvidas com a avaliação participou. $\mathrm{O}$ evento teve a condução da nova diretoria do Inep, que ainda não se apropriara da história da avaliação. E, como foi muito mal recebido, talvez por uma condução desastrada, uma incapacidade de perceber as forças, os poderes e micropoderes em conflito, todos nós que viemos ao Inep depois tivemos de responder por isso por um longo tempo, até sararem as feridas.

GB: Por que pagou o preço? 
DR: Porque muitas pessoas achavam que eu estava vinculado a esse evento, porque eu era do Inep e o evento tinha sido organizado pelo Inep.

GB: Meses depois!

DR: Claro, meses depois, e eu me perguntava: "Que diabo de evento é esse de que eu não estou sabendo?”. Comecei a pesquisar sobre o evento: perguntava aqui e ali, e sempre a avaliação era péssima. Claro que dizer que eu não estava associado ao evento, que não estava no Inep na época, que só vim em junho e não no início do governo - meio ano depois, portanto tudo isso atenuava. Mas é assim mesmo: quando se assume um cargo, assume-se o ônus e o bônus.

GB: O Cristovam teve relação com a Comissão durante os trabalhos?

DR: Nenhuma; só na divulgação! Quando nós terminamos, apresentamos o documento para ele.

GB: Quem te convidou para o cargo de Diretor de Estatísticas e Avaliação do Inep?

DR: Fui convidado para o cargo pelo Luiz Araújo.

GB: Ele conhecia você?

DR: Não, também não me conhecia, mas ele era, na verdade, o diretor mais forte do Otaviano, e o Otaviano deve ter dado a ele a atribuição de me convidar. Depois o Otaviano me ligou também, mas só depois que o canal já estava aberto. Segundo o Otaviano me disse, ele teria ido a um encontro dos pró-reitores de graduação e perguntaram quem seria o diretor de avaliação, já que o primeiro tinha renunciado, uns vinte dias depois. Não ficaram sabendo disso?

GB: Não, não me lembro.

DR: O Cristovam colocou um certo Alberto, que era um hablante da língua de Cervantes. Ele ficou cerca de vinte dias no cargo. Daí perguntaram para o Otaviano quem seria o substituto desse Alberto, e ele teria dito algo como "não sei, mas estamos pensando no nome de um tal de 
Dilvo Ristoff”, e então teria havido aplausos na plateia. Claro, o ForGrad era meu fórum! O fórum do qual fui vice-presidente e presidente... Disse ele que o nome foi bem recebido e que então ele decidiu ir atrás. Foi a história que me contaram; não sei se é verdadeira. Pode ser que tenham contado só para me agradar. De qualquer forma, convidaram-me. Mas eu não tinha relação nenhuma com eles, nunca tinha visto nenhum deles, não sabia quem eram. Realmente, quando vi pela primeira vez o nome do Otaviano como presidente do Inep, fui pesquisar e descobri que ele tinha sido presidente da Adusp [Associação dos Docentes da Universidade de São Paulo].

GB: Ele é novamente o presidente da Adusp agora.

DR: Mas, veja bem, o que é a Adusp no contexto da avaliação? Para nós não tinha relação alguma.

GB: Diga o que aconteceu na reunião de apresentação do Sinaes, especialmente entre a Eunice e o Zé Dias. Eu soube por uma matéria de jornal, depois ouvi que tinha sido um momento marcante.

DR: É, foi um momento importante, sim; talvez mais por marcar a posição do Sinaes em relação ao Cristovam do que por qualquer outro motivo. $\mathrm{Na}$ verdade, o evento só aconteceu porque o Cristovam não adotava o Sinaes como proposta do MEC. Ele visivelmente não estava satisfeito, eu posso garantir isso.

GB: Mas se ele tinha participado... Ele era reitor quando foi realizada a avaliação institucional na UNB, não? E a posição dele nessa época, não se sabe? DR: Não! Ele não se envolveu. E quando caiu nas mãos dele aquele "tijolo", um texto grande, repleto de propostas, o professor José Dias preparou um PowerPoint e fez uma apresentação para ele. Pude ver - enquanto o Zé falava -, na expressão de seu rosto, que ele não estava gostando, que queria algo puxando muito mais pro lado de um Ides mesmo.

GB: Já nesse momento? 
DR: Já, ele queria uma coisa muito mais "pão, pão, queijo, queijo", rápida, de fácil consumo, que desse uma boa visibilidade na mídia no dia seguinte. O impacto na mídia sempre valeu mais para o Cristovam do que a importância no campus. O Cristovam, lamentavelmente, parecia ser totalmente movido pela mídia.

GB: Todos eles são.

DR: O Cristóvam me pareceu ganhar de todos. Até do Paulo Renato.

GB: Mais que o Paulo Renato?

DR: Acho que sim. O problema é que, quando o indivíduo é movido pela mídia a tal ponto, ele se torna um other-oriented man, ao invés do inner-oriented man. Estou falando da categorização feita nos anos 50, por David Riesman. Ele publicou um livro no qual faz essa categorização. O inner-oriented man é o indivíduo que trabalha a partir de princípios que internalizou ao longo de sua história. O mundo para ele acaba sendo, em grande parte, guiado por esses princípios; em seu encontro com o mundo, ele vai eliminando o que não lhe serve, enquanto petrifica cada vez mais seus princípios básicos. O other-oriented man, por outro lado, em seu encontro com o mundo, torna-se um canibal cultural, social: ele vai se redesenhando permanentemente, à medida que as coisas vão surgindo; canibaliza isso, aquilo, e, de repente, descobre-se que nem ele sabe mais o que é.

GB: Carnavaliza? Ou canibaliza?

DR: Canibaliza mesmo! Você devora o outro e o torna parte de si mesmo.

GB: Vamos falar do Sinapes. Houve a Medida Provisória lançada no fim da gestão do Cristovam, com a criação do Sinapes; depois ele saiu e, no Congresso, foi aprovado o Sinaes. Como foi esse processo e que articulações políticas ocorreram para essas mudanças?

DR: O que posso dizer? A Medida Provisória caiu do céu; ninguém sabia da existência dela até ser publicada. Como o Cristovam não gostava do Sinaes, ficou construindo um substituto - o Sinapes. Ele fez uma versão 
básica do Sinapes e distribuiu-a para nós, que fizemos duas reuniões para discuti-lo; na primeira, ele chegou com um PowerPoint e queria apresentar, mas não conseguiu sair das primeiras lâminas. Sua proposta foi tão detonada, as críticas a ela tão veementes e as perguntas tão numerosas que ele não conseguiu avançar. Das reuniões, participaram 17 pessoas que, para mim, não tinham qualquer conexão com a história da avaliação. Grande parte era funcionários da casa, outros ligados ao gabinete. Havia, também, pessoas ligadas à Capes, entre elas um professor da UnB, cujo nome não me lembro mais.

GB: Não é o Marcel Burstyn?

DR: Isso mesmo, o Marcel!

GB: Eu andei pesquisando, ele é sociólogo, algo na área de humanas, surpreendeu-me.

DR: Era novamente um grupo novo, que de repente surge do azul do céu e não tinha nada a ver com a história da avaliação. Nós começamos a discutir o tal do Sinapes do Cristovam. Depois, quase ao final, eu lhe perguntei se ele tinha lido minhas contribuições ao Sinapes. Eu havia lido o texto atentamente, fui lendo e marcando tudo o que eu achava que tinha de ser diferente, a começar pelo próprio nome...

GB: Falávamos do Sinapes, que o professor Cristovam estava expondo, e você fez referência a suas conclusões sobre esse sistema de avaliação.

DR: O texto do Cristovam devia ter umas seis páginas; eu me lembro que devo ter acrescentado, pelo menos, mais umas onze páginas de comentários ao texto dele. Só que ele não fez referência alguma a meus comentários, foi apresentando do jeito que o texto dele estava e, então, eu não consegui me conter e perguntei: "Ministro, o senhor leu as contribuições que eu mandei? Eu trabalhei bastante no texto, o senhor leu?". Ele disse: "Li sim, li sim! Nossas discordâncias são apenas operacionais". Então eu disse: "Não, ministro, não são só operacionais, são conceituais também". Aí ele disse: "Então a gente volta a conversar na quinta-feira". Isso 
aconteceu numa terça-feira à noite, por volta das $9 \mathrm{~h}$, e na quinta-feira aconteceu a segunda reunião. Eu fui preparado para essa reunião.

GB: Que articulações políticas ocorreram então para as mudanças no Sinapes, na Medida Provisória, no Sinaes?

DR: Não ocorreram articulações políticas; aconteceu uma mudança no Ministério, só isso. Cristovam foi demitido; como se sabe, a relação dele com a Casa Civil não era boa, já há algum tempo, e ele foi exonerado. Quando foi feita a troca de ministros, eu já tinha ido embora, para casa, para não voltar mais. Com a chegada do Tarso Genro como ministro, o quadro mudou significativamente. Já na primeira entrevista que o Tarso deu no Bom Dia Brasil - nunca vou me esquecer - , declarou que aquela Medida Provisória ia ser revista. Eu disse para mim mesmo: "Beleza! Temos luz no fim do túnel”, e, quando voltei dos feriados, fui chamado. Cheguei e fui imediatamente chamado ao gabinete do ministro, pediram-me para reescrever a Medida Provisória. Eu comecei a reescrever e apresentei a nova versão. Fizemos várias reuniões seguidas, várias, várias, e cada vez que eu lia e discutíamos, eu dizia: "Há isso aqui e aquilo lá que também teria de mudar", mas estava meio constrangido em fazer mudanças muito radicais, porque, afinal de contas, a MP tinha sido assinada pelo Lula, não só pelo Cristovam. Então a orientação foi: "Vamos mudar tudo que nós achamos que temos de mudar". E assim foi sendo elaborado o projeto de conversão. Trabalhamos diretamente com o relator, na Câmara, para que a mudança fosse absorvida, porque a Câmara votaria a MP. Então, ele apresentou esse projeto de conversão que, basicamente, nós elaboramos. Quando digo "nós", estou falando da equipe nova do Tarso, com o Jairo Jorge, o Eliezer Pacheco, eu - e, claro, ouvimos as pessoas ligadas ao Sinaes.

GB: E como ele sabia do Sinaes, alguém tinha dado algum passo para sensibilizá-lo?

DR: Certamente o pessoal da Casa Civil, quando foi decidido colocar o Tarso ali, orientou-o sobre isso, mas posso lhe garantir que eu não tive 
participação direta nisso. Embora eu conhecesse o Tarso, lá de Porto Alegre, eu tenho certeza de que ele não sabia quem eu era.

GB: O Hélgio não participou?

DR: Só na reescrita.

GB: Não, não; na sensibilização do Tarso.

DR: O Hélgio pode ter trabalhado na sensibilização, não saberia dizer.

GB: Eu não sei se ele estava aqui...

DR: Não, naquela época o Hélgio não estava no MEC. Ele passou alguns meses na França, e é possível que tenha feito essa articulação direto com o Tarso, pois tinha uma relação muito próxima com ele. É possível que tenha alertado o Tarso. O Hélgio não participou em quase nada, nem mesmo na reescrita da Medida Provisória. Participou muito pouco, na verdade, tanto que foi uma surpresa que, depois, ele tenha acabado como presidente da Conaes.

GB: E no Congresso, como foi a sensibilização?

DR: No Congresso foi um trabalho diuturno nosso com o relator, o doutor Evilásio Vieira, de São Paulo.

GB: E foi somente com ele?

DR: Principalmente. Claro que nós conversamos com o Gaston Vieira também. Conversamos com os líderes de todas as bancadas. O José Dias Sobrinho e eu fizemos um trabalho inclusive com o PSDB, por meio dos irmãos dele, ambos senadores. Almoçamos com os dois.

GB: Álvaro Dias.

DR: Isso mesmo! Visitamos também o outro irmão dele, o Osmar Dias, que também estava no Senado. Aproveitamos o contato com o Álvaro, no mesmo dia, e falamos com o líder do PSDB, Arthur Virgílio. E dele tivemos a garantia de que iria nos apoiar. Enfim, assim fizemos muitos contatos, especialmente eu e especialmente eu e o pessoal da Assessoria 
Parlamentar do MEC, dentre eles uma moça que trabalhava na articulação institucional do MEC e que foi uma pessoa muito importante neste processo, pois conhecia meio mundo lá no Congresso e foi abrindo os canais de comunicação para mim.

GB: Ela é de onde, do Inep? Da Casa Civil?

DR: Não, não! Ela era e é da assessoria parlamentar do MEC. Mas, claro, nós negociamos tudo com o pessoal da Casa Civil, que veio ao Inep várias vezes. Na construção do Sinaes, a Casa Civil participou ativamente com três advogados, presentes constantemente. Também tivemos ajuda dos advogados do próprio MEC, além da ajuda dos advogados do Inep. Nunca vi tanto advogado por metro quadrado como naqueles dias. E, claro, tivemos a participação do professor Mario Pederneiras e da Sesu. O Mário Pederneiras participou de forma um tanto errática. Ele nunca estava presente do início ao fim; ou seja, participou, mas nunca de forma muito convincente. O Mário tinha muitas outras atribuições, então não conseguia assumir as rédeas ou acompanhar a discussão do início ao fim. Isso é muito complicado, tanto que aquela expressão "referencial básico" foi dele. Eu tinha colocado "a avaliação será a base da regulação", e ele, por alguma razão, não concordou. Ele disse: "base, não", e eu disse "base, sim"; aí ele disse: "referencial básico". Eu disse: "tudo bem”, também está ótimo. Depois, para minha surpresa, ele deu a entender que não concordava com sua própria expressão.

GB: Por quê?

DR: Porque esse artigo tinha implicações maiores do que talvez ele tinha inicialmente imaginado. Implícita estava toda uma mudança de enfoque no comando da avaliação e da regulação. Aquele artigo estabeleceu que a avaliação seria de responsabilidade do Inep e que seria referencial básico nos processos de regulação entre eles - a autorização de cursos, o reconhecimento e a renovação de reconhecimento e o credenciamento e recredenciamento de instituições. Ou seja, nós estávamos dizendo que a avaliação, no âmbito do Sinaes, não era só para quem já estava 
no sistema, mas para quem estava entrando no sistema de Educação Superior. Isso era uma mudança radical, porque jogava toda a avaliação para o Inep, tirando-a da Sesu, da Setec e da Secretaria de Educação a Distância. Isso tinha algumas implicações: a Sesu, num primeiro momento, pelo menos, interpretou isso como um esvaziamento do papel dela. Não era nada disso: estávamos pondo ordem na casa, para não ter uma coisa fracionada. Nós estávamos criando uma avaliação com uma orientação geral única.

GB: Nunca se pensou em criar uma agência de avaliação, não como a Conaes, mas que concentrasse todas as funções dispersas no Inep (e que continuam de alguma forma dispersas, porque quem faz a regulação é o Ministério e quem faz a avaliação é o Inep)?

DR: Não, nunca se pensou em criar uma agência que fizesse isso.

GB: A estrutura da qual você fala, que fazia as avaliações havia anos no Inep (e depois com a inclusão da educação a distância), não estaria um pouco desproporcional, adquirindo o Inep um peso maior?

DR: Com certeza! Se você organizasse o Inep com duas diretorias fortes, uma diretoria de Educação Superior e uma de Educação Básica, a Diretoria de Educação Básica ganharia uma dimensão enorme. Por exemplo, por que os censos da Educação Básica estão fora da Diretoria de Educação Básica? O Educacenso poderia estar na Educação Básica, e ela ganharia uma dimensão gigantesca, com 50 milhões de estudantes e mais de 1 milhão e 800 mil docentes. O que eu quero dizer é que podia ser uma diretoria exatamente equilibrada. O Enem tem três milhões de estudantes fazendo uma prova dez vezes maior que a do Enade, embora menos complexa que este. O Enade é mais complexo porque tem de fazer um exame para cada área do conhecimento e também porque o sistema de Educação Superior é basicamente federal, o que significa dizer que ele depende da União para seu processo regulatório. Já na Educação Básica isso não ocorre. Então, o que temos de diferente são as avaliações in loco. São coisas diferentes, mas em termos de tamanho e importância, essas atividades poderiam estar 
perfeitamente distribuídas em duas diretorias, e então não falaríamos de hipertrofia de nenhuma delas.

GB: O que você acha da criação de uma agência de avaliação?

DR: Poderíamos criar uma agência de avaliação, sem problema nenhum, mas não considero isso uma questão vital. A pergunta é outra: queremos uma avaliação de caráter compulsório - como temos hoje - ou não? Acho que essa é a questão preliminar. Se quisermos uma avaliação de caráter compulsório, estaremos necessariamente colocando o Estado no meio dessa briga, dizendo que as IES e os cursos necessariamente têm de passar por essas avaliações se quiserem funcionar legalmente.

GB: Mas essa agência não pode ser estatal?

DR: A agência pode ser estatal, sem problema algum, mas o que eu quero dizer é que, de certa forma, o MEC acaba sendo essa agência. Hoje não vejo a necessidade de se criar outra, porque a concepção de avaliação não vai mudar enquanto tivermos uma Constituição que diz o que ela diz e uma LDB que diz o que ela diz. Hoje, gostemos ou não, a avaliação e a regulação estão inextricavelmente ligadas.

GB: O fato de órgãos diferentes realizarem a regulação, a supervisão e a avaliação não poderia causar atritos?

DR: Os atritos, hoje, são frequentes. Poderia gerar atritos de outra natureza. Talvez até pudesse ser mais saudável, porque hoje, por exemplo, quando a Sesu ou a Setec não estão satisfeitas com uma avaliação feita pelo Inep, elas devolvem a avaliação e dizem: "Eu recorro dessa avaliação". De ofício, elas podem recorrer e podem perfeitamente dizer: "Essa avaliação aqui está insuficiente e vamos buscar mais informações”. Elas podem fazer isso! A avaliação, afinal, é referencial básico e não único, e isso pode se repetir com a agência também. Não vejo realmente diferença nisso. O importante é perceber que há uma diferença fundamental entre um sistema de acreditação no qual o avaliado diz: "Eu vou me submeter à avaliação porque quero o selo de qualidade do $\mathrm{MEC}$, porque 
isso me garante prestígio na sociedade e reputação diante da comunidade, o que pode aumentar inclusive o número de pessoas que nos procuram. Com o selo MEC de qualidade, nós vamos ter alunos melhores e em maior número". Ter ou não ter o selo MEC de qualidade faz toda a diferença na acreditação. Mas hoje, e aqui, não é assim, porque enquanto a avaliação estiver vinculada à regulação, ela é obrigatória e, portanto, ter não faz tanta diferença, porque todos têm de ter. E se e quando todos têm a mesma coisa, ela deixa de ser um elemento de distinção. Só que alguns vão ter "três", outros vão ter "quatro", e, como todos os que funcionam a rigor têm isso em suas médias, ou seja, como essas distinções não são muito rigorosas, tudo acaba tendo um valor idêntico, tornando-se lugar comum. Pessoalmente, resumindo, eu preferiria ter um sistema de avaliação com adesão voluntária, mas penso que está superado hoje no Brasil.

GB: A sociedade brasileira está preparada para um sistema de acreditação? DR: A sociedade brasileira não aceita mais isso, ela desenvolveu um humor punitivo muito forte. Ela acha que o Estado tem de ter uma força muito maior do que tem e maior do que a que se vê manifesta em outros países na questão da avaliação e da acreditação. Também percebo que, em países que adotaram a acreditação como modelo, o obrigatório foi substituído não pelo opcional, mas pelo optatório.

GB: Na Argentina, por exemplo.

DR: Criam-se constrangimentos em substituição à força da lei. Então, sinceramente, acredito que outro modelo poderia ser melhor, mas não estou convicto de que, neste momento histórico, vale a pena comprar essa briga. Preciso me convencer melhor, a partir dos exemplos que vem de outros países, de que os resultados vão ser muito diferentes ou melhores.

GB: Ou piores...

DR: Podem até ser piores! Por isso, prefiro direcionar meus esforços para fazer o melhor possível com o que temos. 
GB: Na proposta da CEA, haveria uma dimensão um pouco mais operacional da Conaes, que depois ficou no Sinaes?

DR: Totalmente. A Conaes da CEA era uma, a Conaes do Sinaes é outra!

GB: E por que isso mudou?

DR: Mudou porque houve uma percepção de que não se pode negar a história. Nós tínhamos uma história de oito anos de Provão, vários anos de Saeb, outros tantos de Enem, alguns anos de avaliação in loco etc. E uma história de comissões de especialistas e de avaliações in loco sendo feitas, todas pelo Inep. Estávamos diante de uma estrutura chamada Inep, com 70 anos de história - um instituto que reunia todos os dados da Educação Básica e da superior, com cadastros de todas as instituições de Educação Superior e de todos os cursos de graduação. O que se percebeu, ao longo do caminho, foi que criar uma nova estrutura naquele momento poderia ser muito mais custoso, difícil de administrar, e talvez não desse os mesmos resultados. Talvez eu tenha contribuído mais do que ninguém para que isso fosse percebido. Por exemplo, a redação do artigo $2^{\circ}$, que estabeleceu que a avaliação deveria ficar sob responsabilidade do Inep, teve uma forte participação minha, não tenha dúvida disso! Eu pensava e continuo pensando assim, que ela tem de ser feita no Inep. E mais, que tem de ser feita com base em uma concepção comum, dada pela Conaes, mas por uma Conaes entendida como um órgão definidor de diretrizes. No modelo da CEA, no entanto, a Conaes era semelhante à Coneau Argentina em seu modo de fazer avaliação. Penso que na Argentina até pode funcionar, mas há uma ressalva: a Argentina fez 100 avaliações em 10 anos. Trata-se de outro sistema...

GB: E não abriu para o setor privado, né?

DR: Justamente porque não abriu para o setor privado. O setor privado argentino é praticamente inexistente. Fazer 100 avaliações institucionais, em dez anos - dez por ano - é incomparável com a realidade brasileira. Nós fazemos em torno de 27 avaliações por dia! Quando eu assumi a Diretoria de Avaliação do Inep, havia aproximadamente 13 mil cursos, e, quando deixei o instituto, havia 26 mil cursos - isso em apenas quatro 
anos e meio. Essa percepção algumas pessoas não tinham, e elas achavam que era possível pegar o modelo de outro país e resolver os problemas de avaliação aqui. Isso se resume numa questão muito simples: não se pode tratar uma "questão de metrópole" com "cabeça de vilarejo". O Brasil não é um vilarejo, pequeno e aconchegante. O sistema de Educação Superior, do jeito que está organizado, é um sistema federal, grande e impessoal ele é 93\% federal e 7\% estadual. Então, nesse sistema, que inclui o setor privado, não dá para pensar pequeno.

O que temos, repito, é um sistema grande e em expansão - um sistema que o Brasil quer continuar a expandir. Imagine fazer todas essas avaliações com uma comissão que se reúne uma vez por mês!

GB: Seria preciso montar outra organização.

DR: Teríamos de montar outro Inep, é isso que eu estou dizendo. Valeria a pena montar outro Inep, ou seria melhor usar uma estrutura que já existia, que já estava funcionando, mesmo que com algumas deficiências? Enfim, esse era o contexto!

GB: Por que dez dias após ser promulgado o Decreto-Ponte foi criada a CTAA - Comissão Técnica de Acompanhamento da Avaliação —, que não estava prevista?

DR: A CTA foi criada muito antes de a CTAA ser criada no Decreto-Ponte; ela já existia. Eu mesmo criei a CTA e assinei a portaria, quando estava na presidência do Inep. Fiz a portaria no Inep e [criei] uma Comissão Técnica para nos assessorar nos processos que envolviam recursos contra a avaliação. Essa primeira Comissão chamava-se CTA (Comissão Técnica de Avaliação), que funcionou por um ano, antes da CTAA a que você se refere. Em princípio, ela não é do Decreto-Ponte.

GB: E por que não foi colocada no Decreto-Ponte?

DR: Porque não havia necessidade. 
GB: Quando analisamos as normas, isso causa certa surpresa. Foi promulgada essa lei e, então, criaram a CTAA; mas quando isso estava previsto? Não pensaram que era necessário operacionalizar os recursos, ou algo assim? Havia certa ambiguidade em relação à Conaes, não?

DR: A Conaes poderia ter funcionado perfeitamente como órgão recursal, mas nós queríamos mais do que um órgão puramente recursal, nós queríamos um que nos ajudasse a, de fato, operacionalizar e que não se reunisse para definir grandes diretrizes. Porque começar a definir grandes diretrizes em geral significa não operacionalizar. Só que o trabalho da CTAA é braçal, debruçar-se sobre uma avaliação e dizer algo como: "A avaliação foi feita, mas aqui há uma incoerência entre isto e aquilo, entre a nota e o parecer...”. Como é que se resolve essa contradição? Que posição tomar? A instituição está certa ao entrar com recurso contra a avaliação ou não? Ou, como nós colocamos depois na CTAA, como vamos viabilizar as regras de constituição do Banco de Avaliadores?

\section{GB: Do Basis.}

DR: As regras de constituição do Basis foram definidas pela Conaes. As regras de constituição efetiva do banco e de constituição das comissões são outras coisas, muito mais práticas, operacionais em sua essência. Então, a CTA cuida desse nível operacional, com o Inep. O Cristovam, na medida provisória dele, tinha pensado numa Conapes e numa Conav, lembra-se?

GB: Eu ia perguntar se você era ciente disso: Conapes e Conav.

DR: Claro! Antes de existir a CTAA, repito, eu criei a CTA, com esse nome, Comissão Técnica de Avaliação. Ela funcionou por um ano, mas o Ministro não gostou dela, e acho que ele estava certo, porque depois de um ano eu também comecei a não gostar. Porque nós tínhamos de institucionalizar isso, com regras muito mais claras. Eu tinha feito minhas próprias regras, porque estava com muita pressa! Precisava resolver as dificuldades do Inep, então disse: "Vamos trazer gente de instituições privadas, gente de instituições públicas, gente do Norte, do Nordeste, de universidades, de centros, de faculdades para nos ajudar". Só que, na CTAA, nós seguimos outra lógica: 
escolhemos as pessoas por área do conhecimento e criamos um mandato com renovação, com atribuições muito mais detalhadas e específicas. Então a CTAA, por exemplo, hoje não se renova cem por cento, ela se renova parcialmente, para dar continuidade. Ela fez um trabalho muito importante para a construção do Basis. A CTAA, hoje, está institucionalizada.

GB: Você concorda com a visão de que o Sinaes é uma metamorfose de elementos anteriores das políticas de avaliação? Ou seja, do PAIUB surge a inclusão da autoavaliação; da avaliação das condições do ensino surge a avaliação dos cursos; e algumas coisas vieram da Medida Provisória do Cristovam, do Sinapes... É isso mesmo?

DR: A avaliação de cursos não é da portaria do Cristovam. Ela é anterior, bem anterior: tem a ver com uma avaliação que já existia nos governos passados.

GB: Por isso, exatamente, a questão é que os elementos anteriores são acumulados no Sinaes e ressignificados: do PAIUB, a autoavaliação; da ACE - Avaliação das Condições de Ensino - a avaliação de cursos do Sinaes; e do Provão, o Enade, acumulados e metamorfoseados, porque eles não são os mesmos...

DR: Você esqueceu de uma parte importante!

GB: Da avaliação externa.

DR: Da avaliação institucional.

GB: As dimensões das leis do Sinaes foram herdadas do PAIUB?

DR: Não, elas são diferentes. O PAIUB ainda estava voltado para a avaliação de cursos.

GB: Sim, o PAIUB começou pelos cursos, mas o próprio nome dele se refere à avaliação institucional.

DR: No Sinaes desenvolvemos outra visão, totalmente nova, do que significa avaliação institucional. A definição de dimensões, no Sinaes, para avaliação institucional é diferente das dimensões de avaliação de cursos; 
é outro tipo de olhar. Esse é o grande diferencial do Sinaes. O Enade é também diferente da avaliação de cursos, mas a avaliação de cursos existe desde as comissões de especialistas da antiga Sesu; ela também não veio da ACE, teve sua origem nas comissões de especialistas.

Portanto, o novo, mesmo no Sinaes, estruturalmente falando, é a avaliação institucional, porque a avaliação que se chamava de institucional no PAIUB não era sinônimo da que nós chamamos de avaliação institucional no Sinaes. Nem de longe! São definições diferentes: a palavra é a mesma, mas o significado é outro, representando algo bem diferente.

GB: Na verdade, o que eu lhe perguntei foi sobre a autoavaliação.

DR: A ideia da autoavaliação veio, de fato, do PAIUB.

Mas a autoavaliação do PAIUB também estava essencialmente associada a cursos. Isso é o que eu quero destacar! Frequentemente, quando se falava em avaliação institucional, falava-se, a rigor, em coisas como avaliação do docente pelo discente, no âmbito estrito e restrito do curso. O pessoal chamava isso tudo de avaliação institucional. Eu quero dizer que nós redefinimos o termo no Sinaes, e isso gerou uma nova visão, um conceito novo, definido em lei.

GB: Por isso nós falamos de cumulação e metamorfose...

DR: Entendo! Mas por que você resiste a dizer "inovação"?

GB: Não vemos assim.

DR: Porque o institucional é, efetivamente, inovação; é novo! Você não encontra em lugar nenhum essa definição de institucional! Se conseguir encontrar, avise-me que eu quero ver! Não existe, na trajetória brasileira, essa definição. No Brasil a avaliação institucional sempre esteve vinculada a cursos. Então, insisto, essa definição é nova; não é mera metamorfose. Não tente diminuir o poder inovador do Sinaes.

GB: Rothen e eu escrevemos isso num artigo intitulado "Sinaes contraditórios: considerações sobre a implantação do Sistema Nacional da Educação Superior". 
DR: Não conheço, mas insisto, não é mera metamorfose. Vocês estão esquecendo e menosprezando a parte mais importante do Sinaes. Afinal, não estabelecemos dez longas dimensões em lei por nada!

GB: Sim, eu concordo com isso. Nós também, em outros artigos, afirmamos isso. Inclusive em um que está sendo agora encaminhado à revista Ensaio, no qual, embora falamos de metamorfose de instrumentos, destacamos a institucionalização do Sinaes como sistema e com leis aprovadas pelo Congresso etc. Estamos reconhecendo, sim, mas não porque seja negativa essa cumulação e metamorfose.

DR: Trata-se de uma nova síntese. É esse o termo que usamos no livro azul, o livro em que foi publicada a proposta inicial.

GB: Porque de alguma forma se está recuperando a história, e vocês falavam muito disso em entrevistas.

DR: Sempre falei, muito abertamente, que nós aproveitamos a história existente e que não escrevemos o Sinaes sobre uma página em branco. Aliás, toda a ideia também da avaliação no Inep está associada ao aproveitamento do que existe. Ninguém de bom senso chega ao governo e joga fora tudo o que existe simplesmente porque existe. Só um tolo poderia imaginar que seria possível refazer o PAIUB, tal qual ele foi concebido originalmente, dez anos depois. Isso seria fazer de conta que a história não existiu nesses dez anos e que a educação viveu num vácuo. A história aconteceu e aconteceu de forma marcante: por exemplo, todo o aparato legislativo foi reforçado no sentido que ele tomou com o Provão. Isso aconteceu depois do PAIUB. O que se dizia na proposta do candidato Lula, que nós iríamos rever a avaliação à luz dos princípios do PAIUB, foi, de fato, à luz. Só que essa luz iluminou nosso caminho e "disse": "Atenção: tem história aqui! Vamos considerá-la ou não?". Por exemplo, na CEA, o Provão era algo que todos queriam ver extinto! Era quase universal a posição de que não deveria haver mais Provão, mas a realidade da história nos dizia que existia um artigo na LDB exigindo uma prova. A pergunta era: "Nós vamos querer mudar a LDB agora?"; e a resposta era invariavelmente: 
"Nós vamos levar dez anos para mudá-la! E então o governo terá acabado e não teremos feito mudança alguma!".

GB: E o Banco Mundial?

DR: O Banco Mundial evidentemente manifestou preocupações muito claras sobre o fim do Provão!

GB: Isso porque eles estavam financiando essas provas? E continuam?

DR: Não sei exatamente como está hoje. Em 2004, quando o Brasil justificou o segundo empréstimo, algo em torno de 500 milhões de dólares, o exame era um dos itens da proposta, no âmbito do Ministério da Educação, de empréstimo para o governo como um todo. O Banco Mundial encomendou inclusive um estudo comparando o Enade com o Provão.

GB: Aquele feito pelo Bob Robert Verhine.

DR: Exato!

GB: Ele publicou o artigo na Ensaio.

DR: Publicou. É um artigo bem elogioso ao Enade. Inclusive com entrevista feita em um momento em que nós ainda tínhamos muitas incertezas sobre como devia ser o Enade. A CEA concluiu seus trabalhos sem definir com clareza o que e como seria o Enade. Estava tudo por fazer!

O Enade era uma coisa chamada Paideia. O Paideia era um exame ligado a quatro grandes áreas e que, evidentemente, não tinha possibilidade nenhuma de ser vinculado aos conteúdos curriculares ou às diretrizes curriculares nacionais. Então, ele ia na contramão direta do Provão e impossibilitaria qualquer tipo de avaliação de curso; e mais: seria feito por amostragem. Aquele modelo de exame, em primeiro lugar, era quase impossível de ser operacionalizado, pois seria tão genérico que não teria condições de avaliar o crescimento de nenhum curso. Por isso decidi que o significado da palavra "área" teria de ser definido melhor. Não podíamos ficar com "grande área", tinha de ser área num sentido mais restrito; assim, área passou a significar conjunto de cursos. Curso tem de 
ter administração, e área, por sua vez, está em todos os lugares! Penso que essa definição me ajudou a flexibilizar a interpretação. Na medida do possível, eu tentei ser o mais fiel escudeiro do Paideia, ou seja, tentei garantir a ideia dos dois momentos do exame, mantendo a preocupação com a formação geral - a ideia de analisar a trajetória do estudante. Enfim, o que foi possível salvar do Paideia, eu salvei. Mesmo assim, tínhamos dúvidas sobre se devíamos fazer uma prova ou duas. Eu mesmo fiquei isolado nessa posição, pois meus assessores achavam que deveríamos ter duas. Eu defendia uma e, claro, imaginava uma prova que contemplasse todos os aspectos da formação de um indivíduo numa área. Penso que vingou, pelo menos em alguns casos... Mas poderia ter sido melhor! Eu diria que nós fomos, de fato, vitimados pelo Provão, por causa de algumas comissões que estabeleceram as diretrizes da prova e comissões que elaboraram as provas por meio das agências responsáveis por essa elaboração. Velhos hábitos custam a morrer, e algumas delas estavam tão habituadas a fazer as coisas de determinado jeito que não conseguiam imaginar algo diferente. Lembro-me bem de uma reunião em Belo Horizonte, quando uma agência nos procurou, em meio a um evento, para nos dizer que era impossível fazer um exame do tipo proposto pelo Enade!

GB: As agências terceirizadas que realizam as provas?

DR: Exato! A agência mal era contratada e já dizia que não conseguiria fazer aquele tipo de exame. Tivemos uma longa discussão até convencê-los de que era, sim, possível. Mesmo assim, fomos um pouco contaminados pelo conteudismo do Provão, mas acho que aos poucos o Enade está melhorando.

GB: Quer falar algo mais sobre o Enade? Qual é sua avaliação sobre esse exame?

DR: Talvez uma das melhores ideias que eu tive para o Enade foi fazer o relatório por curso e divulgar um para cada um dos milhares de curso do Brasil, porque ele é extremamente importante. Fizemos, também, um relatório por área, e no ano passado fizemos o primeiro relatório por instituição. Esses relatórios, somados aos resumos técnicos - que não eram nada 
resumidos - e aos boletins individuais e "tabelões" de conceitos, formavam um conjunto de informações destinado aos principais grupos de interesse: os professores, os coordenadores de curso, a mídia, os alunos, os pais dos alunos e o grande público. Cada relatório tem seu leitor preferencial.

GB: Qual era a visão da mídia durante o tempo em que você foi Diretor de Avaliação? Houve estratégias específicas para a divulgação do Sinaes?

DR: Sempre trabalhei, repito, com a ideia de que tínhamos vários públicos, entre eles: um público especialista, que queria um relatório por área; um público de uma comunidade acadêmica específica, que queria um relatório por curso; e o grande público, que tem a mídia como mediadora. Por isso, todos esses relatórios eram diferenciados! Mas é importante atentar para o seguinte: cada Enade teve e sempre terá seu tema do ano...

Como a mídia via o Enade no início? Em geral, bem no início, a mídia não parava de criticar e de falar mal, porque achava que não tinham de mudar o Provão. A virada veio, ironicamente, quando divulgamos os resultados do último Provão, em dezembro de 2003. A repercussão na grande imprensa foi extraordinariamente positiva. Tivemos inclusive um editorial altamente elogioso da Folha de S. Paulo. O que houve de diferente? Tudo! Abrimos os números que geravam os conceitos e os apresentamos numa escala de 0 a 100 - algo que todo mundo entende; assim mostramos quão enganoso os conceitos poderiam ser. Isso, aliado a uma contextualização dos dados nas diferentes categorias administrativas, regiões, organizações acadêmicas etc., foi um prato cheio. A mídia adorou. Então eles viram que o tom era muito diferente, que nosso trabalho tinha conteúdo e estávamos fazendo mudanças de fundo.

Nós estávamos lançando o último Provão e mostramos que era possível fazer diferente. Isso criou expectativas positivas em relação à avaliação: se era possível fazer algo tão diferente com o velho, imagine o que seria o novo! Acho que naquele momento abriu-se muito o canal de comunicação. No ano seguinte, quando foi divulgado o primeiro Enade, as manchetes focaram na formação geral, mostrando que os concluintes e os ingressantes tinham praticamente o mesmo desempenho em formação 
geral etc. Essas foram as manchetes; claro que podiam ter sido sobre muitas outras coisas, mas foram as preferidas do Tarso... Como não havia formação geral antes e como a formação geral era comparável entre as áreas, a novidade ocupou a mídia durante duas semanas, pelo menos. A mídia gosta de novidade, o que explica esse sucesso. No ano seguinte, no segundo Enade, a manchete foi o lançamento do IDD, o indicador de diferença entre o desempenho projetado e o observado; já a manchete do terceiro ano foi sobre o desempenho comparativamente positivo dos alunos do Prouni.

GB: E sobre a educação a distância.

DR: O Enade gerou tantas matérias que os jornalistas poderiam ficar ocupados por meses sem que se perdesse o interesse. Minha sensação é de que só temos três jornais no Brasil — os outros são todos retransmissores deles, no que diz respeito às manchetes. Então, se a Folha apresenta uma matéria boa, todos os jornais do interior vão reproduzi-la. Claro que, na academia, surgem coisas muito diferentes.

GB: E quanto ao grande público da televisão?

DR: Também na TV o Enade teve boa repercussão. Por exemplo, a questão dos alunos do Prouni virou notícia no Jornal Nacional, a questão do primeiro Enade também.

GB: Vocês traçaram algumas estratégias para isso?

DR: Simplesmente tivemos sempre a preocupação de apresentar muitas informações ao grande público, sem esconder nada. As matérias sobre os perfis dos estudantes, por exemplo, mostram que havia grande interesse em saber quem eram nossos alunos. Sempre ajudei a traduzir isso para os jornalistas, até porque eu conhecia os dados melhor do que eles; isso gerava em mim a necessidade de ajudá-los a compreender e a esclarecer ao grande público. Trabalhávamos muito, em todas as frentes possíveis - a questão racial, a questão de classe, a questão de escolaridade dos pais, a do desempenho dos alunos trabalhadores etc. - , tudo era assunto. 
GB: Ou seja, vocês interpretavam?

DR: Também! Nosso primeiro cuidado era apresentar os números dos resultados com clareza, de forma muito didática, ou seja, de forma que "comuns mortais" pudessem compreender o que estava sendo discutido. Também submetíamos uma descrição dos dados no resumo técnico, na qual estavam evidentemente presentes nossas preocupações com as questões da Educação Superior. Nenhuma descrição é neutra; ela sempre mostra nossas preferências, isso é inevitável. Consciente disso, eu sempre terminava os resumos técnicos com uma frase mais ou menos assim: "Essas são apenas algumas das muitas inferências que podem ser produzidas a partir dos dados do Enade. Outras podem ser produzidas a partir das tabelas anexas.". Nossas descrições e inferências ajudaram a mídia a traduzir os números para o grande público e, por isso, a repercussão foi razoavelmente boa. Temo que, se isso for interrompido - como tudo indica que vai acontecer - pela nova estrutura, perca-se boa parte desse trabalho. A mídia precisa de ajuda para interpretar. Não adianta simplesmente dar um "tabelão" para a mídia; é preciso criar alguns enfoques, porque se ela tiver de fazer todo o trabalho, talvez o abandone. É importante, portanto, que ela tenha acesso aos dados de forma privilegiada e oportunidade de estudá-los e aprofundá-los. Todos os que têm acesso privilegiado aos dados têm a obrigação de produzir algum tipo de interpretação, inclusive o Inep. Se alguém discorda dessa interpretação, ótimo, apresente outra; para isso, ele terá os mesmos dados disponíveis. E se precisar de outros para gerar novos cruzamentos, deve ter acesso facilitado a eles. Interpretação é isso. Por exemplo, pelos meus cálculos, cruzando os números do Censo da Educação Superior com os do Censo da Educação Básica, concluo que o Brasil necessitará de 84 anos para formar os professores de Física de que hoje necessita na Educação Básica. Pode ser que alguém venha com uma interpretação brilhante e me diga que dá para fazer em cinco! Não tem problema; só me diga como isso será feito e me mostre os dados que fundamentam a inferência. Dados sem inferências são dados estéreis e sem significado, e inferências produzidas sem dados são ocas e incapazes de sustentar políticas públicas de forma duradoura e convincente. 